\title{
Distinguishing Kaolinites and Smectite Clays from Central and Eastern Uganda Using Acidity, pH, Colour and Composition
}

\author{
I. Z. Mukasa-Tebandeke ${ }^{1}$, P. J. M. Ssebuwufu' ${ }^{1}$, S. A. Nyanzi' ${ }^{1}$, A. Schumann², M. Ntale1, \\ G. W. Nyakairu' ${ }^{1}$, F. Lugolobi ${ }^{3}$ \\ ${ }^{1}$ Department of Chemistry, Makerere University, Kampala, Uganda \\ ${ }^{2}$ Department of Geology, Makerere University, Kampala, Uganda \\ ${ }^{3}$ Department of Earth Sciences, Wesleyan University, Middletown, USA \\ Email: ${ }^{\text {ishamukasa@cns.mak.ac.ug }}$
}

Received 1 October 2014; accepted 19 October 2014; published 14 January 2015

Copyright (C) 2015 by authors and Scientific Research Publishing Inc.

This work is licensed under the Creative Commons Attribution International License (CC BY). http://creativecommons.org/licenses/by/4.0/

c) (i) Open Access

\begin{abstract}
The Langmuir isotherms of 1-aminobutane in isohexane slurries showed increase in clay acidity with increase in concentration of mineral acid used to leach the clay as well as the temperature at which the clay was thermally activated prior to experimentation involving adsorption of 1-aminobutane. The values of acidity for Central Uganda were low ranging from $0.07 \mathrm{~mol} / \mathrm{g}$ to 0.32 $\mathrm{mol} / \mathrm{g}$ yet those for clays from Eastern Uganda were high ranging from $0.1 \mathrm{~mol} / \mathrm{g}$ to $1.85 \mathrm{~mol} / \mathrm{g}$. Based on acidity, $\mathrm{pH}$, elemental and mineral compositions, the clays from Central Uganda were found to be kaolinites or halloysites, yet Eastern Uganda clays were resolved to contain nontronite and kaolinite.
\end{abstract}

\section{Keywords}

Surface Acidity, Adsorption, 1-Aminobutane, pH, Isotherms, Kaolinite, Smectite

\section{Introduction}

Clays are collectively called alumino-silicates as they contain aluminium oxide and silicon dioxide as universal minerals; and are classified into phyllosilicates and layers silicates [1].

As early as the 1940s, the active part of a cracking clay catalyst had been described to be the $\mathrm{Al}$ (IV) ion and

"Corresponding author.

How to cite this paper: Mukasa-Tebandeke, I.Z., Ssebuwufu, P.J.M., Nyanzi, S.A., Schumann, A., Ntale, M., Nyakairu, G.W. and Lugolobi, F. (2015) Distinguishing Kaolinites and Smectite Clays from Central and Eastern Uganda Using Acidity, pH, Colour and Composition. American Journal of Analytical Chemistry, 6, 58-70. http://dx.doi.org/10.4236/ajac.2015.61006 
found to occupy only a small part of the surface. This active part of aluminium in four coordinate forms constitutes acidity [2]. The smectites have high cation exchange capacity (CEC), and kaolinites have negligible CEC [3].

Clays change their surface properties when leached with acids. Acid leached smectites have been used in oil industries as catalysts, filter aid and bleaching agents [4]. Acid-leached clays show different characteristics from their raw counter parts; for example they show higher acidity and bleaching capabilities than raw clays [5].

In a study aiming at determining the surface acidity changes resulting from acid treatment of clays, a volumetric titration method was used [6]-[8]. In this method, $0.5 \mathrm{~g}$ of clay, previously dried, was put in a conical flask to which $15 \mathrm{~cm}^{3}$ of $0.1 \mathrm{MNaOH}$ was added. After stirring the flask for 10 minutes, the clay was titrated with 0.1 $\mathrm{MH}_{2} \mathrm{SO}_{4}$ acid using phenolphthalein indicator. Acidity was then determined as milliequivalents of $\mathrm{NaOH}$ used per $100 \mathrm{~g}$ of clay.

According to the concepts independently proposed by J.M. Broensted and T.M. Lowry [9] in 1923, an acid is any hydrogen containing species which can release a proton and a base is any species that accepts a proton. The equilibrium attained is

$$
\mathrm{HA}+\mathrm{B} \longrightarrow \mathrm{A}^{-}+\mathrm{HB}^{+}
$$

where $\mathrm{HA}$ is acid and $\mathrm{A}^{-}$is conjugate base

In the same year a different approach was proposed by G.N. Lewis [10], which defines an acid as any species which has an incomplete electronic grouping that can accept an electron pair to give rise to a coordination bond. The base is any species that possesses a non bonding electron pair that can be defined by the reaction:

$$
\mathrm{B}:+\mathrm{A} \longrightarrow \mathrm{B}-\mathrm{A}
$$

The interactions of clay surfaces with gases or liquids that are used in adsorption and catalysis are governed by the acid-base strengths [11] [12].

Clay minerals have been shown to possess attractive properties as solid acids [13] [14] and these surface properties are associated with acidity brought about by Broensted and Lewis centres.

The adsorption of 1-aminobutane on selected clays used in the study produced adsorption isotherms of the first class type according to the Brunauer classification [15] [16] shown in Figure 1. The chemical interaction between the adsorbate and surface is consistent with the Langmuir adsorption isotherm equation 1.0 given below.

$$
\mathrm{c} / \mathrm{n}=(1 / \mathrm{Knm})=\mathrm{c} / \mathrm{nm}
$$

where $\mathrm{c}$ is the concentration of substrate in solution that is in equilibrium with the adsorbed substrate, $\mathrm{K}$ is the kinetic equilibrium constant of adsorption, $\mathrm{n}$ is the amount of adsorbed substrate per gram of solid, and $\mathrm{nm}$ is the monolayer coverage, which corresponds to the theoretical amount of solute that covers all the sites in $1.0 \mathrm{~g}$ of sample.

The surface acidity of clays is strongly related to adsorptive tendencies of clays. It is on this ground that determination of surface acidity of raw and acid-leached clays has to be determined. The surface acidity of clays of Uganda has never been published, so the objectives of this study are to elucidate surface acidity of the selected clays and use it to distinguish kaolinites from smectites.

\section{Materials and Methods}

\subsection{Sampling}

Clay samples were collected from

1) Central Uganda; this will be at the following areas:

a) Kajansi in Wakiso District.

b) Seeta and Lwanda in Mukono District.

c) Kawuku and Nakawa in Kampala District.

2) Eastern Uganda; this will be at the following areas:

a) Umatengah, Chodah, and Kumi in Kumi District.

b) Mutufu and Budadiri in Sironko District.

c) Siron, and Chelel in Kapchorwa District.

14 samples of clays were collected from regions reported to contain mainly kaolinite and six samples from 


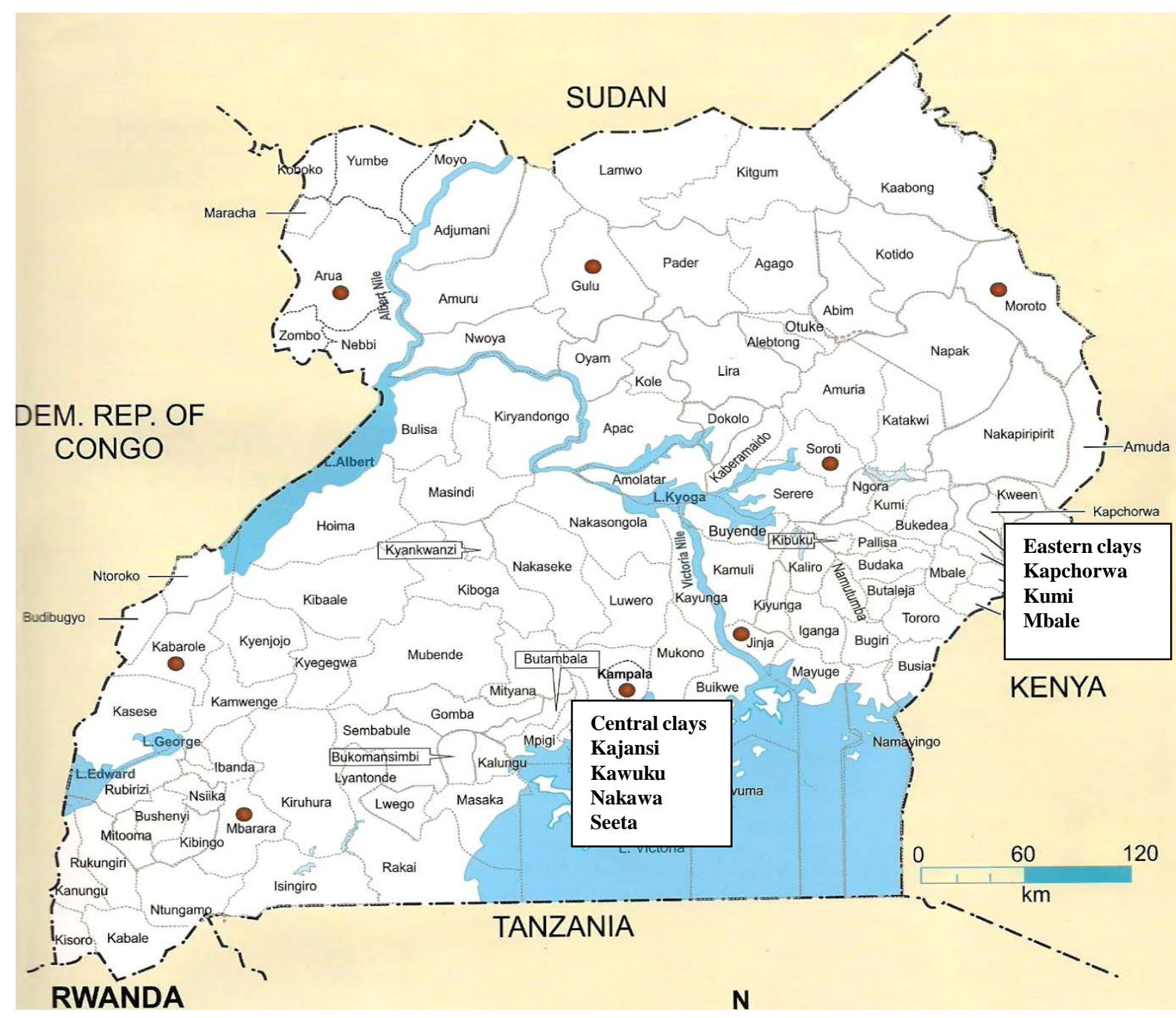

Figure 1. Location of sample collection sites.

regions suspected to contain smectites. In most cases, the clays were dug up from virgin mines except for Kajansi, Seeta, Budadiri and Lwanda deposits where clay mines were fully operational. The samples were collected at depths in the range of $35-150 \mathrm{~cm}$ from the surface to minimize effect of weathering and contamination.

\subsection{Preparation of Clays}

Raw samples of clays were separately soaked, stirred to dilute slurry in distilled water, sieved to pass through a mess $5.3 \times 10^{-4} \mathrm{~m}$ diameter, dried at $105^{\circ} \mathrm{C}$ and ground to powder using a rolling mill. The clay powders were stored for future use in desiccators.

\subsection{Determining pH of Clay}

Weighed clay powder $(1 \mathrm{~g})$ was placed in a beaker, water $(20 \mathrm{~mL})$ added. The mixture was stirred continuously and allowed to equilibrate for 30 minutes at $25^{\circ} \mathrm{C}$. A calibrated $\mathrm{pH}$-meter was then used to read the $\mathrm{pH}$ of the solution. The method was repeated thrice to get comparing results, whose average was recorded

\subsection{Leaching of Clays}

Clay powder $(100 \mathrm{~g})$ was mixed with acid $(500 \mathrm{~mL})$ of appropriate concentrations $(0 \%, 5 \%, 10 \%, 20 \% \mathrm{v} / \mathrm{v})$ in a flask. The mixture was heated at $105^{\circ} \mathrm{C}$ for 4 hours; then cooled and filtered. The residue was washed to neutral- 
ity with distilled water; then dried at $105^{\circ} \mathrm{C}$ in the thermo-stated oven. The dried leached powders were labeled and stored for future use.

\subsection{Determination of Surface Acidity of Clays}

Activated clay powder ( $0.2 \mathrm{~g})$ was placed in a flask. $1.0 \times 10^{-2}$ M1-aminobutane solution in isohexane (20 mL) was added. The flask was stoppered and shaken vigorously for 20 hours using an electric shaker at room temperature. The equilibrium mixture was filtered. Portions of the filtrate $(5.0 \mathrm{~mL})$ were pipetted to a clean flask, extracted with water $(5.0 \mathrm{~mL})$; methyl orange indicator (2 drops) added and the mixture titrated with $0.004 \mathrm{M}$ hydrochloric acid to orange endpoint [6]-[8] [17]. For each clay sample activated at a particular temperature, four entries were entered as a result of the leaching medium. Each clay type was activated by heating at different temperatures in the range between $40^{\circ} \mathrm{C}$ and $80^{\circ} \mathrm{C}$ at internals of $10^{\circ} \mathrm{C}$ from each temperature used. Each analysis was carried out thrice to get comparing results. The data obtained was averaged.

\section{Results and Discussion}

\subsection{Location and Geological Settings of Sampled Clays}

The areas from which the clays were mined are shown in Figure 2 on the map of Uganda. As shown on the map, clays were mined from Central and Eastern Uganda. Nakawa, Lwanda and Seeta clay deposits are located along Jinja-Kampala Highway. Kajansi clay deposits are on Entebbe road in the Swamp of Kajansi River, Kawuku is located on the shores of Lake Victoria off the Gabba road.

Kumi district is located in Eastern Uganda close to the shores of Lakes Kyoga and Bisina. The clays in Central Uganda and Kumi districts are located in regions which are not associated with volcanic margins. The clay deposits in these areas are mainly sedimentary deposits found along river valleys and swamps.

Budadiri and Mutufu clay deposits are found in Sironko district in a characteristically volcanolastic areas of mountain Elgon. Chelel and Siron clay deposits are found in Kapchorwa district in areas of past volcanic activity near Kapchorwa town.

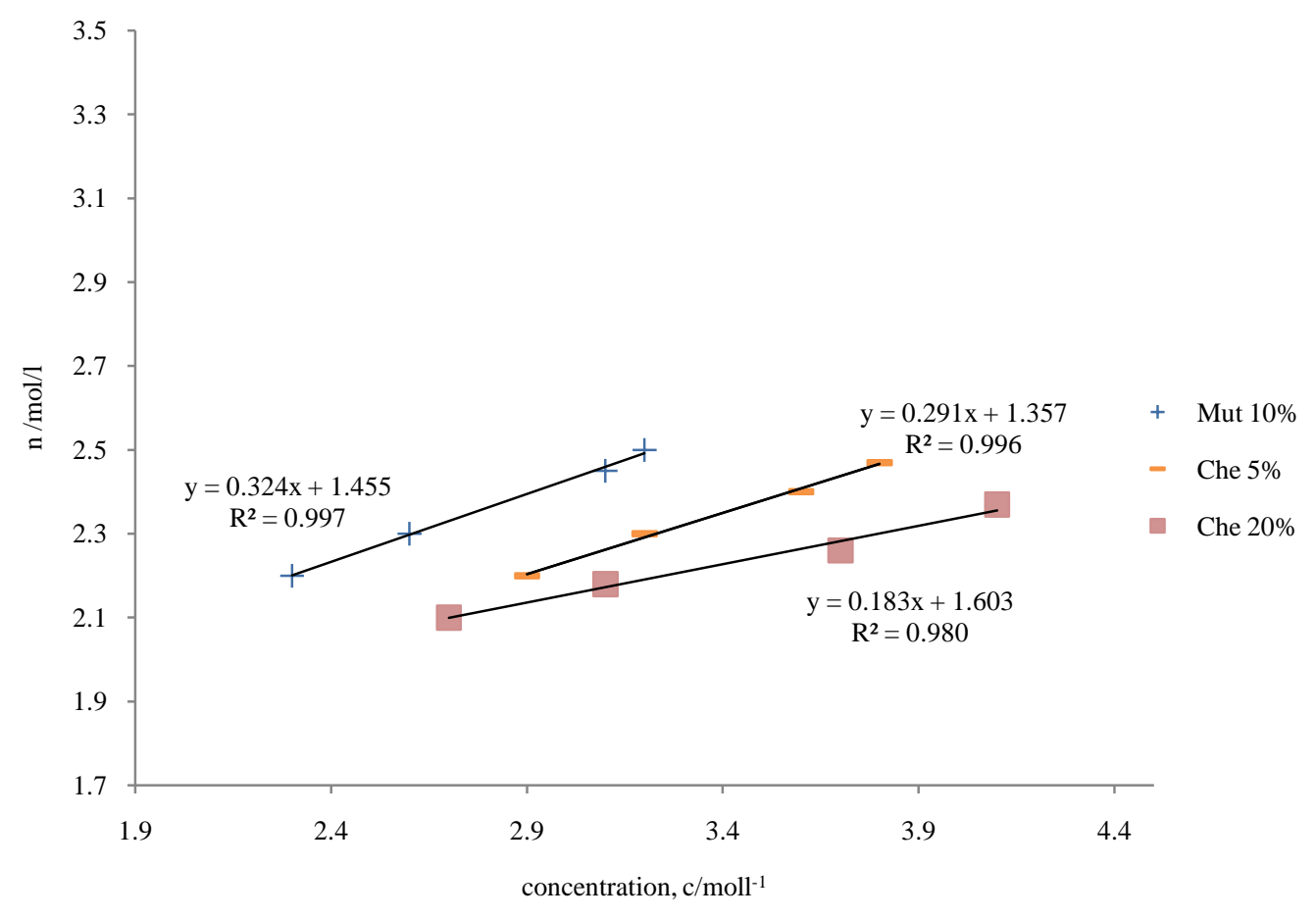

Figure 2. Representative Langmuir adsorption isotherms for 1-aminobutane on smectite clay powders. Key: Mut is Mutufu clay; Che is chelel clay. $5 \%$ is clay leached with $5 \%$ acid; $10 \%$ is clay leached with $10 \%$ acid and $20 \%$ is clay leached with $20 \%$ acid. 


\subsection{Sampling Methods}

14 samples were collected from the regions containing mainly kaolinite and six samples from regions suspected to contain smectites. In all cases the clays were dug from virgin mines except for Kajansi, Seeta, Budadiri and Lwanda where clay mines were operational. The samples were collected at depths in range of $35-150 \mathrm{~cm}$ from the surface to minimize the effect of weathering and contamination.

\subsection{Color and pH of Clays}

Colors and $\mathrm{pH}$ of clays commonly suggest presence of characteristic elements upon which prediction of surface and bleaching properties can be made. Record of average $\mathrm{pH}$ and color of clays may serve as reference to nature of the environment from which the clay sediments were collected.

The clay deposits sampled exhibited different colors depicting differences in composition of trace transition elements composition in the clays. The appearance of most clays depend on the quantity and oxidation state of iron and other transition elements present. While clays containing iron in oxidation state +3 are yellow or brown. Green clays contain iron in oxidation state +2 but colour can also arise from presence of manganese and titanium compounds in different oxidation states [18]-[20].

The colors of selected clays observed in this study are shown in Table 1. The orange, brown and yellow clays were mined from near the earth surface and grey and white clays were mined from deeper deposits. The differently colored clay horizons were shown to contain various transition elements [19] [20].

The determination of $\mathrm{pH}$ of clay slurries in distilled water was repeated thrice and the average of the three values has been tabulated in Table 1 . Readability of $\mathrm{pH}$ was 0.04 .

The colours of the clays sampled varied from black to grey through orange in the deposits at Kajansi, Kawuku, Seeta, Lwanda, Chodah, Ngero, and Umatenga probably due to presence of iron and other metal compounds [21]. Colored clays have interlayer cations as $\mathrm{Fe}^{2+}, \mathrm{Fe}^{3+}, \mathrm{Mn}^{2+}, \mathrm{Ti}^{4+}$ and other transition metal ions. These interlayer octahedral ions are easily replaced by protons during acid activation using low or moderate concentrations

\begin{tabular}{|c|c|c|c|}
\hline Clay & Source & Color & $\mathrm{pH} \pm 0.034$ \\
\hline A & Kajansi & Dark grey & 5.96 \\
\hline B1 & Seeta & Yellow-grey & 6.10 \\
\hline B2 & Seeta & Orange-brown & 4.95 \\
\hline C & Lwanda & Whitish-grey & 5.60 \\
\hline $\mathrm{D}$ & Nakawa & Reddish-brown & 5.75 \\
\hline E & Kawuku & Dark brown & 6.40 \\
\hline $\mathrm{F}$ & Umatenga & Grey-yellow & 6.30 \\
\hline G & Chodah & Grey-yellow & 6.80 \\
\hline $\mathrm{H}$ & Ngero & Dark-grey & 6.60 \\
\hline I1 & Budadiri & Dark brown & 5.60 \\
\hline I2 & Budadiri & Dark grey & 5.65 \\
\hline I3 & Budadiri & Dark grey & 6.50 \\
\hline $\mathrm{J} 1$ & Mutufu & Grey & 6.90 \\
\hline $\mathrm{J} 2$ & Mutufu & Dark grey & 8.40 \\
\hline $\mathrm{K}$ & Siron & Brown & 6.80 \\
\hline $\mathrm{L}$ & Chelel & Whitish grey & 7.90 \\
\hline
\end{tabular}


of the acids [18] [19] to give silica to a large extent.

However, the Kimolian white bentonites were found to have higher brightness, and whiteness index values, and lower yellowness index and the variations in white color were inversely related to the abundance of iron oxides and anatase [22]. The occurrence of iron in the smectite structure and its oxidation state caused variations in color [22].

The selected clay deposits at Siron, Budadiri, Mutufu and Chelel showed colors ranging from brown or orange through grey to white due to presence of iron in different oxidation states as well as difference in the mineralogical compositions in the different strata resulting from the levels of alteration and migration of silica through the mine. Color alone cannot based on to distinguish kaolinites from smectites.

The clays from deposits at Kajansi, Seeta, Lwanda, Nakawa and Kawuku had pH values near 6 showing that they are acidic presumably as result of the natural acidity of the hydroxyl groups on silica sites [23]. 995)

The selected clay samples from Mutufu and Chelel had average $\mathrm{pH}$ ranging between 7.5 and $8.50 \pm 0.034$ because the environment where they were mined is ultra basic. The alkalinity of the clay slurries is attributable to presence of alkali and alkaline earth metals whose silicates strongly hydrolyse raising the $\mathrm{pH}$ above 7 . This showed presence of excess alkali metals like sodium and potassium as well as K-feldspars in these clays. The $\mathrm{pH}$ of slurries for bentonites or montmorillonites was reported to lie in the range between 7.8 and 8.5 [23]-[26]. As the $\mathrm{pH}$ for Mutufu and Chelel clays were as high as those for bentonites from Egypt, Saudi Arabia and Wyoming (USA), it is possible that these clays have high smectite content.

As low $\mathrm{pH}$ of kaolinites is associated with presence of acidic water or ionisable hydroxyl groups on the surface of clays it has been proposed that the slurries of kaolinites ionise. The $\mathrm{pH}$ of slurries of smectite-rich clays is greater than 7 due to hydrolysis of sodium or/and potassium silicates. The hydrolysis may be complete or partial. Therefore the interlayer ions are structurally acting as counter ions to the silicate skeleton in nontronite. $\mathrm{pH}$ measurements can be used to distinguish kaolinites from smectites.

\subsection{Surface Acidity}

It is known that bleaching earths must operate optimally so as to remain affordable. So producers of bleaching clays control surface acidity to guarantee the highest degree of activity [27] with the aim of avoiding hydrolysis of triglycerides by the acid catalysts in presence of moisture originating from the oils or the bleaching clay.

The standard clay suspension in isohexane and standard solution of 1-aminobutane or aminocyclohexane in isohexane followed with determination of free amine concentrations at equilibrium titrimetrically or spectrophotometrically [6]-[8] [15] [28] gave data on acidity.

As the surface acidity of the clays and clay minerals have been found to be due to Lewis and Broensted acidities [15] [29] [30], and found to be closely related to the bleaching capacity [31] and cracking capability [32]. It was necessary to determine the acidity of raw and acid-leached clays used in this study in order to distinguish kaolinites from smectites. The surface acidities of clay samples were determined using 1-aminobutane on the basis that adsorption 1-aminobutane was irreversible.

As far back as the 1960s, 1-aminobutane dissolved in isohexane was directly titrated on clay suspensions in isohexane using bromothymol blue and bromcresol green as indicators [28]. In this study, 1 -aminobutane, $\mathrm{pkb}=$ $10.9 ; \mathrm{kb}=1.26 \times 10^{-11} \mathrm{moll}^{-1}$, was used as a base to determine the total acidity of the differently activated clay powders from Uganda clays.

The mixture of the 1-aminobutane in equilibrium with the strongly agitated clay-amine mixture showed that surface acidity of selected clays increased with increase in the concentration of the acid used to leach the clay as well as increase in temperature at which the clay was activated. This has been shown by the decrease in the quantity of $0.04 \mathrm{M}$ hydrochloric acid required to completely react with the 1-aminobutane in equilibrium with the clays baked separately at $40^{\circ} \mathrm{C}, 50^{\circ} \mathrm{C}, 60^{\circ} \mathrm{C}$ and $70^{\circ} \mathrm{C}$.

As the leached clays are probably in the acid-form of ion-exchange resin, the 1-aminobutane binds to the clay surfaces either by reacting with the available protons on the surface of the clay or by sharing the lone pair or non-bonding pair of electrons on the nitrogen with the vacant sites on the clay surface. So the surface acidity determined by adsorption of 1-aminobutane corresponds to the determination of both Lewis and Broensted acidities together.

The amount of hydrochloric acid used on 1-aminobutane remaining in solution at equilibrium decreased as the concentration of the acid used to leach the clay increased as well as the temperature of thermal activation 
increased. This showed that the acidity of the clays increased greatly regardless of the composition of the clays. However, the increase in acidity for clays from Mutufu, Chelel, Budadiri and Siron which are richer in smectites was higher than for clays from Kawuku, Nakawa, Chodah, Umatenga, and Seeta, which are richer in kaolinites. Consequently, the clays studied can be distinguished in the kaolinite and smectite groups using surface acidity measurements. This showed the acid-leached clays from volcanic sediments to be better adsorptive materials. So basing on this evidence clays from Central Uganda are kaolinite yet those from volcanic sediments of Mt Elgon are smectites.

The decrease in concentration of 1-aminobutane in $100 \mathrm{~cm}^{3}$ of 0.04 molar solution when shaken to equilibrium with $1 \mathrm{~g}$ of clay was calculated and tabulated as shown in Table 2 .

The data in Table 2 show that there was a strong relationship between the quantity of 1 -aminobutane adsorbed per gram of clay, temperature at which the clay is activated and the concentration acid used in the leaching clays. This relation suggests that the leaching increased the number acid sites in the clay mineral by the removal of exchangeable cations like $\mathrm{Ca}^{2+}$ and/or $\mathrm{Na}^{+}$which lie between the clay layers [11]. When the protons in the acid used to leach the clay replaced the exchangeable ions, Lewis acidity of the clays increased. This led to increased adsorption of 1-aminobutane on clay suspensions used.

However, although removal of octahedral ions like $\mathrm{Mg}^{2+}$ and $\mathrm{Al}^{3+}$ occurred during the leaching of the clays samples, it has been observed that protons from the acid cannot fill in the empty spaces left [15] so the octahedral vacancies remain empty. It has been suggested that the increase in Broensted acidity may be due to the protons of the hydroxyl groups at the corners of the octahedral sites which become more labile because of structural deformation caused by acid-leaching [12]-[15]. The increased acidity upon leaching the clay with acid must be due to the octahedral vacancies left in the clay lattices [6]-[8].

Calculations for the molar concentration of 1-aminobutane present in solution in equilibrium with the adsorbed molecules per gram of clay used were computed and used to plot Figure 2 and Figure 3 to verify if Langmuir adsorption took place. The plot of surface acidity, n, versus the concentration, c, of the 1-aminobutane in equilibrium with clay material gave straight lines for all the clays used in the study at different temperatures

Table 2. Molar concentrations $\times 10^{-3}$ of 1 -aminobutane at equilibrium.

\begin{tabular}{|c|c|c|c|c|c|c|c|c|c|c|c|c|}
\hline $\begin{array}{c}\text { Amount } \\
\text { of acid } \\
\text { added (\%) }\end{array}$ & $\mathrm{Temp} /{ }^{\circ} \mathrm{C}$ & Kajansi & Kawuku & Nakawa & Seeta & Mutufu & Budadiri & Choda & Umatenga & Ngero & Chelel & Siron \\
\hline \multirow{3}{*}{0} & 50 & 3.04 & 2.85 & 3.90 & 3.80 & 4.70 & 4.40 & 4.30 & 3.80 & 3.50 & 5.81 & 4.00 \\
\hline & 60 & 4.03 & 1.90 & 3.00 & 2.80 & 3.80 & 3.90 & 3.75 & 2.70 & 3.10 & 5.31 & 3.20 \\
\hline & 70 & 5.48 & 1.00 & 2.60 & 1.30 & 2.80 & 2.80 & 2.40 & 1.70 & 2.70 & 2.60 & 2.60 \\
\hline \multirow{3}{*}{5} & 40 & 5.04 & 5.30 & 4.90 & 4.54 & 5.38 & 4.40 & 2.15 & 4.00 & 3.10 & 3.62 & 4.50 \\
\hline & 50 & 3.00 & 4.19 & 3.76 & 3.80 & 4.20 & 3.90 & 1.70 & 3.10 & 2.50 & 2.64 & 4.00 \\
\hline & 60 & 1.10 & 2.90 & 2.75 & 2.97 & 3.60 & 2.90 & 1.05 & 2.60 & 2.20 & 1.36 & 3.20 \\
\hline \multirow{4}{*}{10} & 40 & 5.00 & 3.87 & 4.47 & 3.10 & 4.90 & 4.75 & 4.10 & 3.25 & 2.17 & 3.50 & 3.85 \\
\hline & 50 & 3.00 & 2.50 & 3.80 & 2.00 & 3.95 & 4.00 & 2.96 & 2.10 & 2.00 & 2.60 & 3.16 \\
\hline & 60 & 2.00 & 1.60 & 2.90 & 1.74 & 2.30 & 2.90 & 1.50 & 1.90 & 1.30 & 1.62 & 2.20 \\
\hline & 70 & 1.00 & 1.90 & 2.00 & 0.30 & 2.10 & 1.90 & 0.30 & 0.80 & 0.70 & 0.30 & 0.80 \\
\hline \multirow{4}{*}{20} & 40 & 5.50 & 4.30 & 4.87 & 3.52 & 1.60 & 2.75 & 2.75 & 1.00 & 1.55 & 3.00 & 4.39 \\
\hline & 50 & 4.00 & 3.50 & 3.80 & 2.25 & 1.30 & 1.90 & 2.00 & 0.70 & 1.50 & 1.50 & 2.62 \\
\hline & 60 & 2.00 & 2.40 & 2.40 & 1.90 & 1.90 & 1.00 & 1.30 & 0.40 & 1.20 & 1.07 & 1.45 \\
\hline & 70 & 0.80 & 1.70 & 1.90 & 0.30 & 0.80 & 0.80 & 0.50 & 0.10 & 1.00 & 0.20 & 0.10 \\
\hline
\end{tabular}




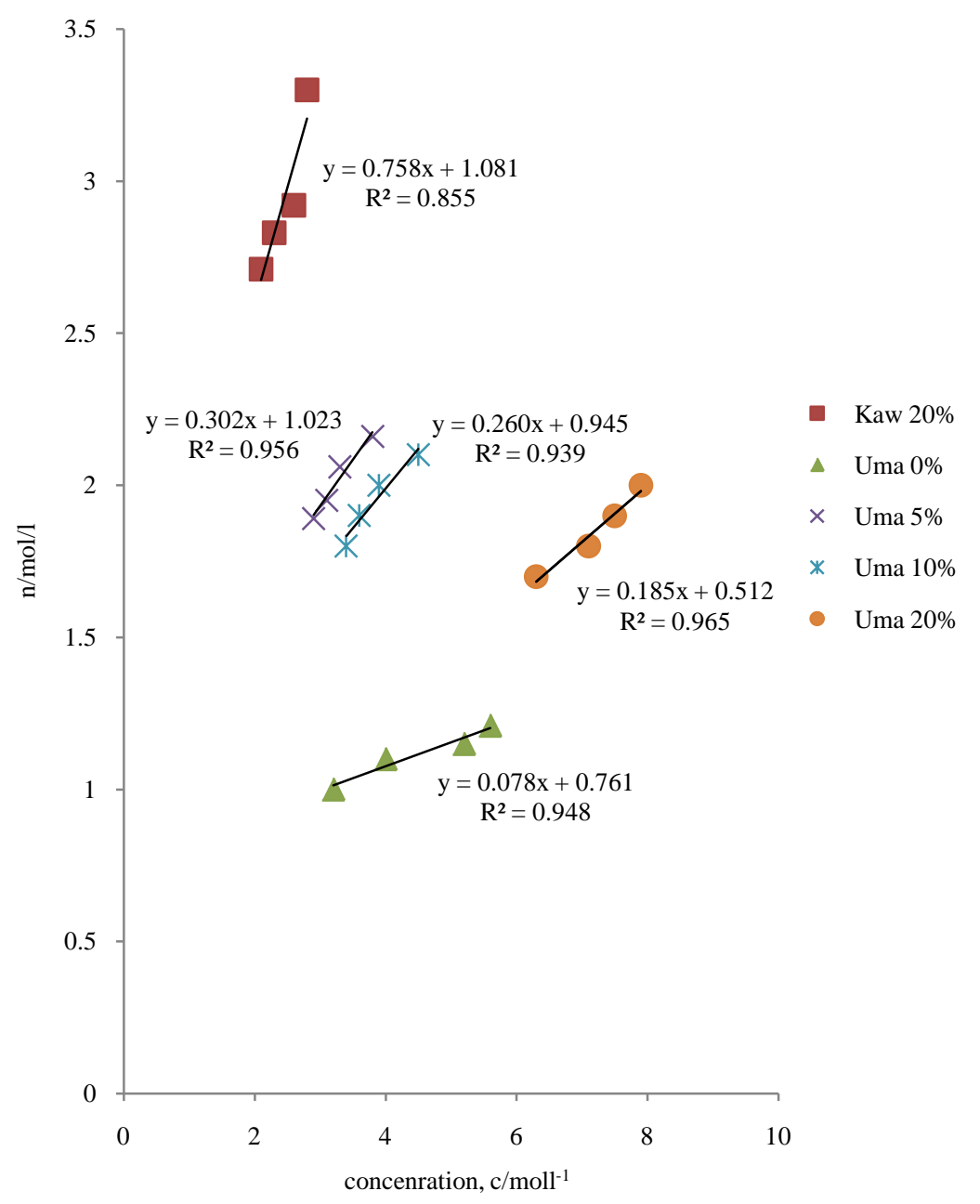

Figure 3. Representative plot of c versus c for adsorption of 1-aminobutane on kaolinite clay powders.

showing that Langmuir adsorption had occurred between the 1-aminobutane and clays. The representative plot of $n$ versus $\mathrm{c}$ is shown in Figure 2 revealed that surface acidity of clay materials used in this study increased with increase in both temperature and concentration of acid used to leach the clay because increase in temperature favoured dissociation of water of crystallisation in the clay exposing more hydroxyl groups. The surface acidity of all clays studied increased as temperature of activation and strength of acid increased showing that replacement for metal ions had been effective. The increase in acidity of clays is shown by the positive slopes of the graphs as shown on Figure 2 and Figure 3 [15].

The increase in amount of 1-aminobutane adsorbed per gram of clay with increase in both concentration of acid used to leach the clay and temperature at which the clay material was activated is explained in terms of increase in number of acid sites created in the clay materials. The increase in slopes of the Langmuir isotherms with increase in concentration of acid used (shown in Table 3 ) has been used to suggest that acidity increased.

The Langmuir adsorption isotherms for the kaolinite rich clays exhibited linearity with $\mathrm{R}^{2}$ value ranging from as low as $0.89 \pm 0.01$ for Seeta and Umatengah clays to as high as $0.998 \pm 0.01$ for Kawuku, Chodah and Kajansi clays. This revealed the acidity of kaolinite rich clays was not strong, so their capacity to bind 1-aminobutane was poor as they could easily reach the saturation point and deviate from linearity of Langmuir adsorption isotherms [33]. The linearity of Langmuir adsorption isotherms developed using clays from smectite-rich sediments from volcanic clays showed $\mathrm{R}^{2}$ value ranging from $0.911 \pm 0.01$ for Budadiri and Siron clays to $0.996 \pm 0.01$ for Mutufu and Chelel clays. The deviation from linearity was explained as arising from adsorption beyond a monolayer which leads to competition between adsorbate molecules [34]. It was noted that non linearity can result 
Table 3. Representative slopes of Langmuir isotherms.

\begin{tabular}{ccccc}
\hline Clay & 0\% Leached & 5\% Leached & 10\% Leached & 20\% Leached \\
\hline Chelel & 0.102 & 0.291 & 0.453 & 1.85 \\
Kawuku & 0.234 & 0.254 & 0.356 & 0.712 \\
Mutufu & 0.131 & 0.212 & 0.324 & 0.452 \\
Umatengah & 0.078 & 0.185 & 0.260 & 0.302 \\
\hline
\end{tabular}

from overcrowding at very high concentrations leading to steric interference between adsorbate molecules [35].

The limiting factor is thermodynamic instability of highly concentrated sample zones which leads to viscous fingering effects [35]. As the smectite-rich clays showed greater degree of linearity for 1-aminobutane adsorption than kaolinite-rich clays, it has been concluded that acid-leached smectites obey Langmuir adsorption more closely than kaolinite-rich clays. In addition, the smectite-rich clays had greater increase in surface acidity and surface area than kaolinite-rich clays [15].

For all the clays tested for acidity under different conditions of temperature and concentration of acid used to activate the clay, the slopes for the Langmuir isotherms were positive showing that acidity and surface areas increased with increase in both temperature and concentration of acid used [15]. The acidity of bleaching clays depends on the degree of activation, the higher the degree of activation, the higher the degree of cation substitution in the structure interlamellar layers by hydrogen ions of the acid used for its activation [15] [28] [30]. That is why smectite-rich clays leached with $20 \%$ acid had higher acidity than those leached with $5 \%$ acid. The leached clays should show a maximum increase in $\mathrm{n}$ at $40 \%$ acid [15].

The data obtained showed gradual increase in acidity of clay and can be used to determine the acidity of the leached clays. The acidity values obtained in these experiments were less than expected from literature [15] [30] because the clays used in the current study were not pure. The Kajansi, Kawuku, Nakawa, Seeta, Chodah and Umatengaclays which are largely kaolinite had smaller acidity values even when leached acid than the Chelel, Mutufu, Budadiri and Siron deposits which contained a smectite called nontronite in the range of $46 \%$ - 50\%.

The increase in acidity with increase in concentration of acid used to leach the clays showed that Lewis acidity greatly increased. It can be inferred that when clay matrices are leached with acids, there is removal of octahedral exchangeable ions like $\mathrm{Na}^{+}, \mathrm{K}^{+}, \mathrm{Ca}^{2+}, \mathrm{Mg}^{2+}$ and $\mathrm{Fe}^{3+}$ [36]. The removal of these ions leaves a siliconoxygen skeleton with octahedral vacant sites. As smectites contain more octahedral ions than kaolinites it has been suggested that clays which showed lower acidity were kaolinites and the ones that attained higher acidity on acid-leaching were smectites. As the concentration of acid used to leach the clay increased, the number of octahedral vacancies increased so acidity of the clay matrices increased.

From the plot of the amount of 1-aminobutane adsorbed per gram of clay at the particular temperature of activation plotted against concentration of 1-aminobutane in solution that is in equilibrium (see Figure 3) for the different clays, there is linear increase in quantity of amine adsorbed from solution showing that acidity increased even with the increase in temperature due dehydration. The variations in $n / c$ versus c shown in Figure 4(a) and Figure 4(b) for the clay materials studied showed the Langmuir adsorption isotherms are valid for the adsorption of 1-aminobutane on clay materials studied. Langmuir isotherms in Figure 4(a) and Figure 4(b) have positive gradients showing that both surface areas and acidity of leached clays increased with increase in temperature and concentration of acid used to activate the clays. The acidity and surface area increased gradually for all the clays tested because the chemical reactions which took place in the structure of the clay during acid-leaching led to removal of some ions giving way to creation of octahedral vacancies in the matrix, so leading to increased Lewis acidity [15].

The Langmuir adsorption isotherms showed that surface areas of the clay materials increased on acid-leaching. The increase in concentration of acid used to leach the clay with increase in linearity of plots in Figure 4 showing that the Langmuir adsorption isotherms are valid for even clays with low smectite content because all leached clays are acidic due to hydroxyl groups. The linearity of Langmuir adsorption isotherms for the kaolinite rich clays showed $R^{2}$ value ranging from as low as $0.89 \pm 0.04$ for Seeta and Umatengah clays to as high as $0.998 \pm 0.04$ for Kawuku, Chodah and Kajansi clays.

This revealed the acidity of kaolinite rich clays was not strong, so their capacity to bind 1-aminobutane was 


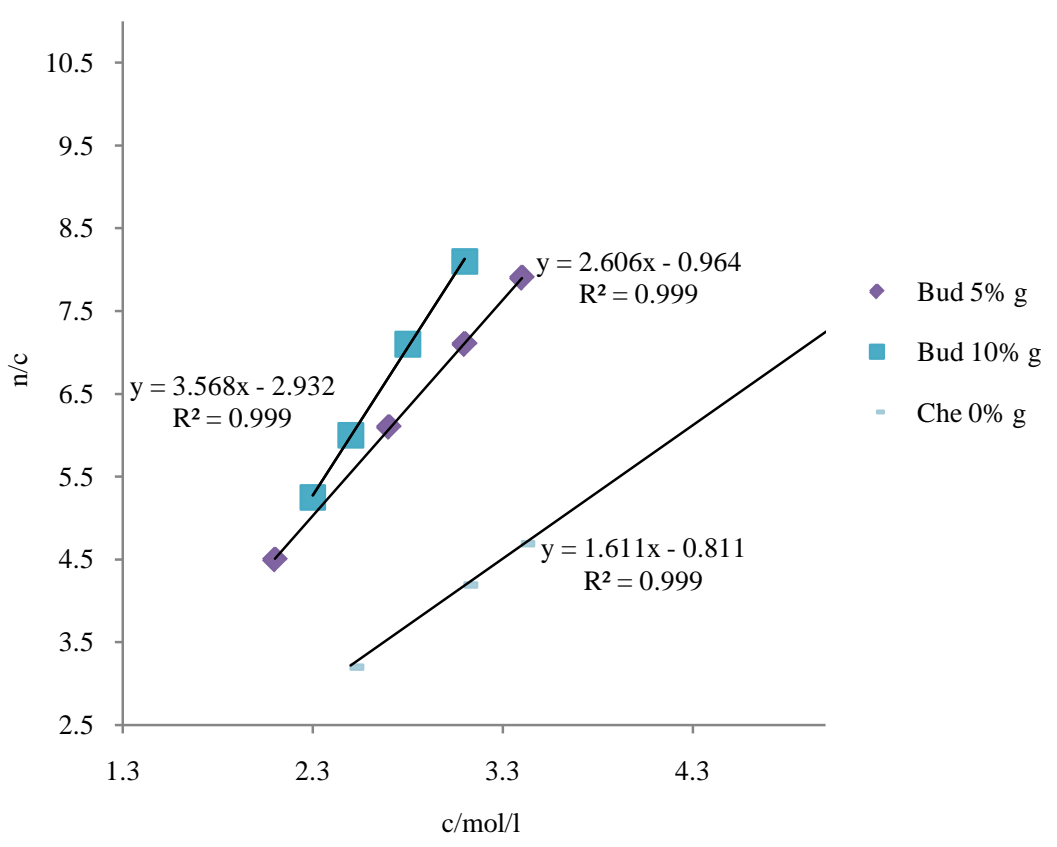

(a)

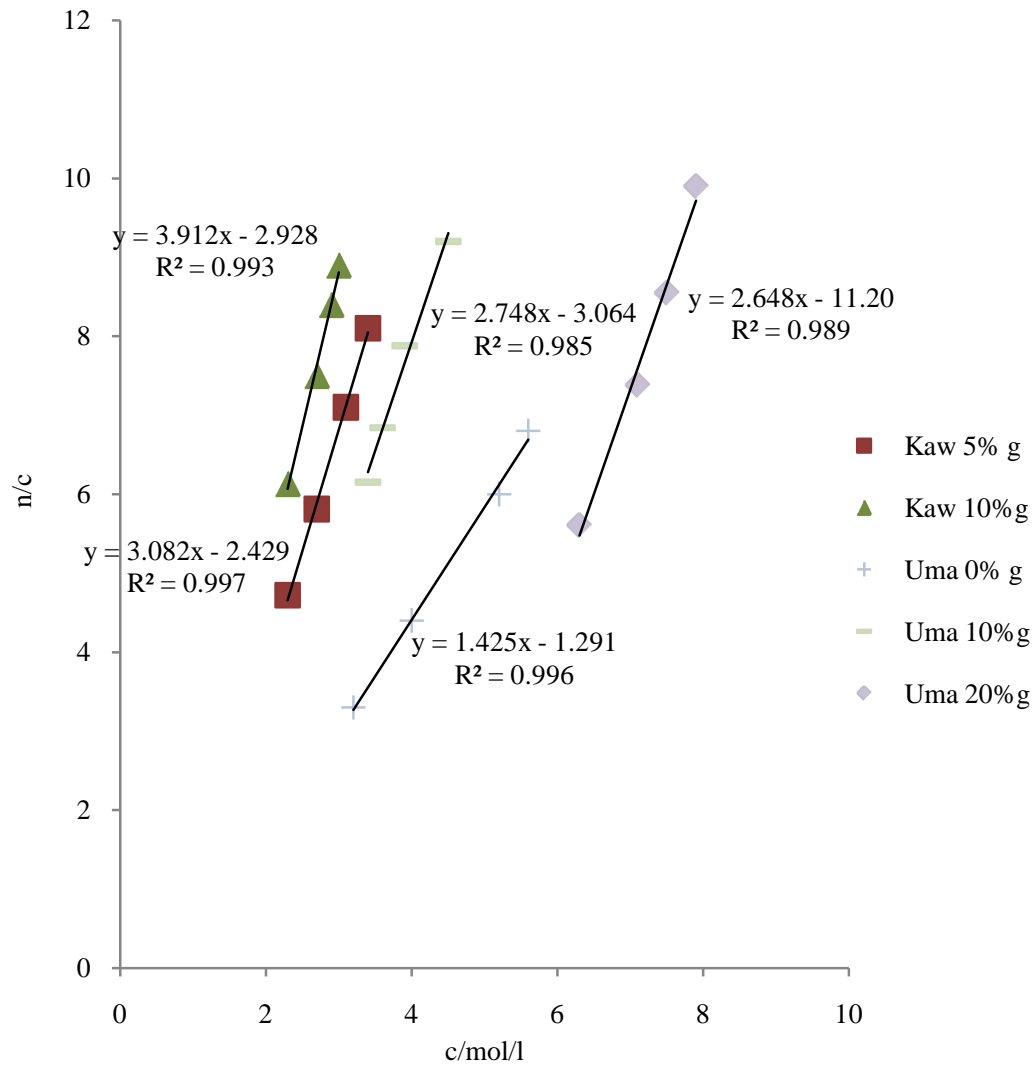

(b)

Figure 4. (a) Representative plot of n/c versus c for adsorption of 1-aminobutane on clays from volcanic sediments; (b) Representative plot of $n / c$ versus c for adsorption of 1-aminobutane on kaolinite clay powders. Key: Bud is Budadiri clay; Che is Chelel clay; $0 \%$ is raw clay; $5 \%$ is clay leached with $5 \%$ acid; $10 \%$ is clay leached with $10 \%$ acid. 
poor because they could become saturated with the 1-aminobutaneeasily [33] [35]. The linearity of Langmiur adsorption isotherms developed using earths from smectite-rich sediments from volcanic clays showed $\mathrm{R}^{2}$ value ranging from $0.911 \pm 0.04$ for Budadiri and Siron clays to $0.999 \pm 0.04$ for Mutufu and Chelel clays and the high level of linearity observed has been explained in terms of capacity to adsorb the amine because they had more acid sites on which the amine could adsorb than kaolinite-rich clays. So the clays could not reach their saturation points easily to involve the adsorbate molecules in competition which leads to steric interactions between the adsorbed and free molecules in solutions [37].

As smectite-rich clays showed greater degree of linearity of 1-aminobutane adsorption isotherms than kaolinite-rich clays (see Figure 3 and Figure 4) it has been suggested that acid-leached smectites obey Langmuir adsorption more closely than kaolinite-rich clays. In addition, the smectite-rich clays undergo greater increase in surface acidity and surface area than kaolinite-rich clays [15]. For all the clays tested for acidity under different conditions of temperature and concentration of acid used to activate the clays, the slopes of the Langmuir isotherms were positive showing that acidity and surface areas increased with increase in both temperature and concentration of acid used. This observation is in agreement with what was reported by earlier authors [15].

The Langmuir adsorption isotherms for clays derived from volcanic sediments showed greater linearity than those from non volcanic clay sediments as shown by their $\mathrm{R}^{2}$ values because acid-leached smectite clays develop higher acidity than kaolinite clays. So their Langmuir isotherms are linear as the clays had capacity to exhibit monolayer adsorption tendencies. Generally the $\mathrm{R}^{2}$ values for kaolinite clays ranged between $0.900 \pm 0.031$ and $0.995 \pm 0.031$ yet that for smectite clays was between $0.96 \pm 0.031$ and $0.999 \pm 0.031$. Under the conditions of this study, the quantity of 1-aminobutane adsorbed was expected to be a linear function of the equilibrium concentration of 1-aminobutane in the solution and the linear relation would signify Langmuir isotherm because the Langmuir equation provides the theoretical adsorption maximum that measures the amine-clay binding energy [38]. However, as concentration rose beyond a critical value, deviations from linearity occurred, showing that there was competition between free amine and adsorbed molecules for the few adsorption sites available in the clay matrices [39].

As both unleached and acid-leached clays irrespective of their mineral compositions showed high degree of linearity of Langmuir adsorption isotherms, it has been proposed that the selected clays had surface hydroxyl or water which easily ionises to release free hydrogen ions. The fact that acid-leached clays showed increasing surface acidity with increase in concentration of acid used to leach the clay revealed that surface hydrogens and hydroxyl groups on the silica skeleton increased. Increase in surface acidity depicted that the interlayer octahedral ions like $\mathrm{Fe}^{3+}, \mathrm{Fe}^{2+}, \mathrm{Mn}^{2+}$, $\mathrm{Ti}^{4+}$ etc were progressively replaced by hydrogen ions as the concentration of the acid increased. This showed that the selected clays conform to structures kaolinites and smectites [40]-[42].

\section{Conclusions}

The pH data on Nakawa, Kawuku, Kajansi, Umatengah, Chodah, Seeta, Lwanda and Kumi clays indicated they are acidic kaolinites as they developed low acidity on leaching. The Mutufu, Budadiri, Siron and Chelel clays have been shown to be smectites as they attained higher acidity on acid-leaching.

As both unleached and acid-leached clays irrespective of their mineral compositions showed high degree of linearity of Langmuir adsorption isotherms, it has been proposed that the selected clays have surface hydroxyl or water which easily ionises to release free hydrogen ions. The fact that acid-leached clays from areas of past volcanism showed increasing surface acidity with increase in concentration of acid used to leach the clay revealed that surface hydrogens and hydroxyl groups on the silica skeleton increased. Increase in surface acidity depicted that the interlayer octahedral ions like $\mathrm{Fe}^{3+}, \mathrm{Fe}^{2+}, \mathrm{Mn}^{2+}, \mathrm{Ti}^{4+}$ etc. were progressively replaced by hydrogen ions as the concentration of the acid increased. This showed that the selected clays conform to structures drawn by earlier authors [40]-[42].

The results on equilibriation of 1-aminobutane with slurries of clay powders in hexane indicated that surface acidity and/or general acidity of clays increased with increase in temperature and concentration of acid used in its activation can be relied on to distinguish kaolinites from smectites.

\section{Acknowledgements}

We thank Mr. Edward Ssekubunga for heating the clay samples studied in the furnace, Mr. Moses Nkolongo (rest in peace) for availing us chance to use the spectrophotometers in the analytical laboratories. We acknowl- 
edge assistance of Professor Ludwig, Mineralogie Institut, Federal Republic of Germany in identifying the clays used in the study.

\section{Recommendations}

The study of 1-aminobutane adsorption on clays should be extended to determination of surface areas of the adsorbent.

\section{References}

[1] Brindley, G.W. (1978) Preparation and Properties of Some Hydroxyl Aluminiumbeidellites. Ceramica, 24, $217-224$.

[2] Ravindra- Reddy, C., Bhat, Y.S., Nagendrappa, G. and Jai Prakash, B.S. (2009) Brønsted and Lewis Acidity of Modified Montmorillonite Clay Catalysts Determined by FT-IR Spectroscopy. Catalysis Today, 141, 157-160.

[3] Bradley, W.F. and Grim, R.E. (1951) High Temperature Thermal Effects of Clays and Related Minerals. American Mineralogist, 36, 182-201.

[4] Kooli, F. and Jones, W. (1997) Characterization and Catalytic Properties of a Saponite Clay Modified by Acid Activation. Clay Minerals, 32, 633-643. http://dx.doi.org/10.1180/claymin.1997.032.4.13

[5] Jadambaa, T., Tsedev, J., Dashdendev, B., Shaarii, E. and Kenneth, J.D.M. (2006) Characterization and Bleaching Properties of Acid-Leached Montmorillonite. Journal of Chemical Technology and Biotechnology, 81, 688-693. http://dx.doi.org/10.1002/jctb.1469

[6] Benesi, H.A. (1957) Acidity of Catalyst Surfaces. II. Amine Titration Using Hammett Indicators. J. Phys. Chem., 61, 970-973 http://dx.doi.org/10.1021/j150553a030

[7] Kumar, P., Jasra, R.V. and Bhat, T.S.G. (1995) Evolution of Porosity and Surface Acidity in Montmorillonite Clay on Acid Activation. Industrial \& Engineering Chemistry Research, 34, 1440-1448 http://dx.doi.org/10.1021/ie00043a053

[8] Cardona-Martinez, N. and Dumesic, J.A. (1992) Applications of Microcalorimetry to the Study of Heterogeneous Catalysts. Advances in Catalysis, 38, 149-244. http://dx.doi.org/10.1016/S0360-0564(08)60007-3

[9] William, M.L. and Hurley, C.N. (2011) Chemistry: Principles and Reactions. 7th Edition, Cengage Learning, Boston, 433.

[10] Harwood, W.S., Herring, F.G., Madura, J.D. and Petrucci, R.H. (2007) General Chemistry Principles and Modern Applications. 9th Edition, Prentice Hall, Upper Saddle River, 695-696.

[11] Jacobs, P.A. (1984) Characterization of Heterogeneous Catalysts. Dekker, New York.

[12] Tanabe, K.K.T., Misono, M., Ono, Y. and Hattori, H. (1989) New Solid Acids and Bases, Their Catalytic Properties. Elsevier, Amsterdam.

[13] Ravichandran, J. and Sivasankar, B. (1997) Properties and Catalytic Activity of Acid Modified Montmorillonite and Vermiculite. Clays and Clay Minerals, 45, 854-858. http://dx.doi.org/10.1346/CCMN.1997.0450609

[14] Tanabe, K. (1970) Solid Acids and Bases. Academic Press, New York.

[15] Alemdaroglu, T. (2003) Investigation of the Surface Acidity of a Bentonite Modified by Acid Activation and Thermal Treatment. Turkish Journal of Chemistry, 27, 675-683.

[16] Gregg, S.J. and Sing, K.S.W. (1997) Adsorption, Surface Area and Porosity. Academic Press, London, 197-199.

[17] Benesi, B.H.C. (1978) Clay Catalysts from Bentonites. Advances in Catalysis, 27, 200-213.

[18] Beneke, K. and Lagaly, G. (2002) From Fuller's Earth to Bleaching Earth: A Historical Note. ECGA Newsletter No 5, 57-78.

[19] Fahn, R. (1976) Bleaching Earths-Preparation, Properties, Practical Applications. Brussels. Chapter 1 International Symposium, Brussels, 28-29.

[20] Nyakairu, G.W.A. and Koeberl, C. (2001) Mineralogical and Chemical Composition and Distribution of Rare Earth Elements in Clay-Rich Sediments from Central Uganda. Geochemical Journal, 35, 13-28. http://dx.doi.org/10.2343/geochemj.35.13

[21] Grim, R.E. and Bradley, W.F. (1940) Investigation of the Effect of Heat on the Clay Minerals Illite and Montmorillonite. Journal of the American Ceramic Society, 23, 242-248. http://dx.doi.org/10.1111/j.1151-2916.1940.tb14263.x

[22] Christidis, G.E., Scott, P.W. and Dunham, A.C. (1997) Acid Activation and Bleaching Capacity of Bentonites from the Islands of Milos and Chios, Aegean, Greece. Applied Clay Science, 12, 329-347. http://dx.doi.org/10.1016/S0169-1317(97)00017-3

[23] Sarikaya, Y., Noyan, H. and Önal, M. (2007) The Effect of Sulphuric Acid Activation on the Crystallinity, Surface Area, Porosity, Surface Acidity and Bleaching Power of a Bentonite. Food Chemistry, 105, 156-163. 
[24] Noyan, H.N., Önal, M. and Sarikaya, Y. (2006) The Effect of Heating on the Surface Area, Porosity and Surface Acidity of a Bentonite. Clays and Clay Minerals, 54, 375-381. http://dx.doi.org/10.1346/CCMN.2006.0540308

[25] Sarikaya, Y., Onal, M., Baran, B. and Alemdaroglu, T. (2000) The Effect of Thermal Treatment on Some of the Physicochemical Properties of a Bentonite. Clays and Clay Minerals, 48, 557-562. http://dx.doi.org/10.1346/CCMN.2000.0480508

[26] Hamza, A. (1966) An Investigation on the Utilization of Egyptian Clays in Bleaching of Cotton Seed Oil. Master's Thesis, Alexandria University, Alexandria.

[27] Mag, T.K. (1990) Bleaching-Theory and Practice. In: Erickson, D.R., Ed., Proceedings of the Edible Fats and Oils Processing World Conference, American Oil Chemists' Society, Champaign, 107-116.

[28] Drushel, H.V. and Sommers, G. (1966) Catalyst Acidity Distribution Using Visible and Fluorescent Indicators. Analytical Chemistry, 38, 1723-1731. http://dx.doi.org/10.1021/ac60244a023

[29] Mokaya, M.P. (2001) Porous Clay Hetero Structures with Enhanced Acidity Obtained from Acid-Activated Clays. Chemical Communications-Royal Society of Chemistry, 3, 2100-2101.

[30] Campelo, J.M., Garcia, A., Gutierrez, J.M., Luna, D. and Marinas, J.M. (1983) Alkali-Promoted AlPO 4 Catalysis: I. Acid-Base and Oxidizing-Reducing Properties. Journal of Colloid and Interface Science, 95, 544-550. http://dx.doi.org/10.1016/0021-9797(83)90213-8

[31] Mills, G.A., Holmes, B. and Cornellius, E.B. (1950) Acid Activation of Some Bentonite Clays. The Journal of Physical and Colloid Chemistry, 54, 1176-1185. http://dx.doi.org/10.1021/j150482a009

[32] Houdry, E., Burt, W.F., Pew, A.B. and Peters, W.A. (1938) Catalytic Processing by the Houdry Process. Nat. Petroleum News, 39, R570-R580.

[33] Nodvin, S.C., Driscoll, C.T. and Likens, G.E. (1986) Simple Partitioning of Anions and Dissolved Organic Carbon in Soil. Soil Science, 142, 27-36. http://dx.doi.org/10.1097/00010694-198607000-00005

[34] Langmuir, I. (1916) The Constitution and Fundamental Properties of Solids and Liquids. Journal of the American Chemical Society, 38, 2221-2295. http://dx.doi.org/10.1021/ja02268a002

[35] Hundal, H.S. (1988) A Mechanism of Phosphate Adsorption on Narrabri Medium Clay Loam Soil. Journal of Agricultural Science, 111, 155-158. http://dx.doi.org/10.1017/S0021859600082952

[36] Balaras, P.K., Lezou, P. and Seiragakis, G. (1999) Mineralogical Society of London. Clay Minerals, 34, $221-312$.

[37] Travis, C.L. and Etnier, E.L. (1981) A Survey of Sorption Relationships for Reactive Solutes in Soil. Journal of Environment Quality, 10, 8-17. http://dx.doi.org/10.2134/jeq1981.00472425001000010002x

[38] Fried, N. and Shapiro, R.E. (1956) Phosphate Supply Patterns of Various Soils. Soil Science Society of America Journal, 20, 471-475. http://dx.doi.org/10.2136/sssaj1956.03615995002000040007x

[39] Olsen, R.S. and Watanabe, F.S. (1957) A Method to Determine a Phosphorous Adsorption Maximum of Soils as Measured by Langmuir Isotherms. Soil Science Society of America Journal, 21, 144-149. http://dx.doi.org/10.2136/sssaj1957.03615995002100020004x

[40] Grim, W.F. (1951) Clay Mineralogy and Petroleum Industry. American Mineralogist, 36, 182-201.

[41] Bain, J.A. and Morgan, D.J. (1989) Laboratory Separation of Clays by Hydrocycloning. Clay Minerals, 18, 33-47. http://dx.doi.org/10.1180/claymin.1983.018.1.04

[42] Bergaya, F. and Lagaly, G. (2013) Handbook of Clay Science. Chapter 1-General Introduction: Clays, Clay Minerals, and Clay Science. Developments in Clay Science, 5, 1-19. 
Scientific Research Publishing (SCIRP) is one of the largest Open Access journal publishers. It is currently publishing more than 200 open access, online, peer-reviewed journals covering a wide range of academic disciplines. SCIRP serves the worldwide academic communities and contributes to the progress and application of science with its publication.

Other selected journals from SCIRP are listed as below. Submit your manuscript to us via either submit@scirp.org or Online Submission Portal.
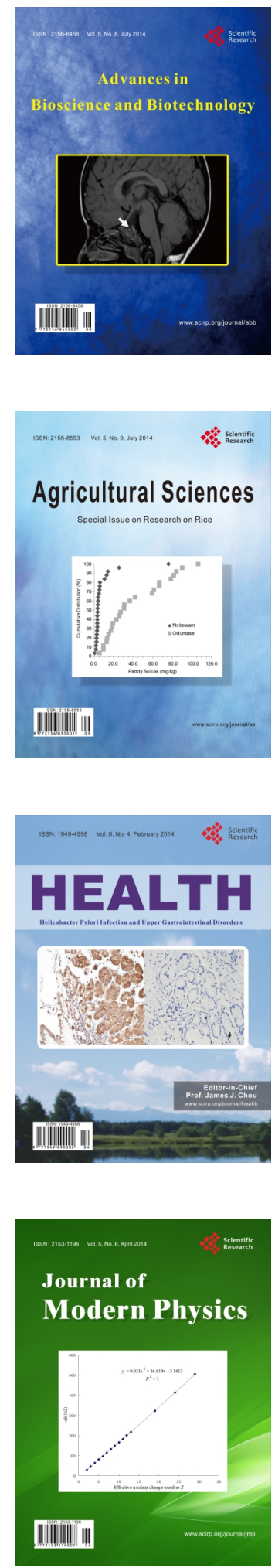
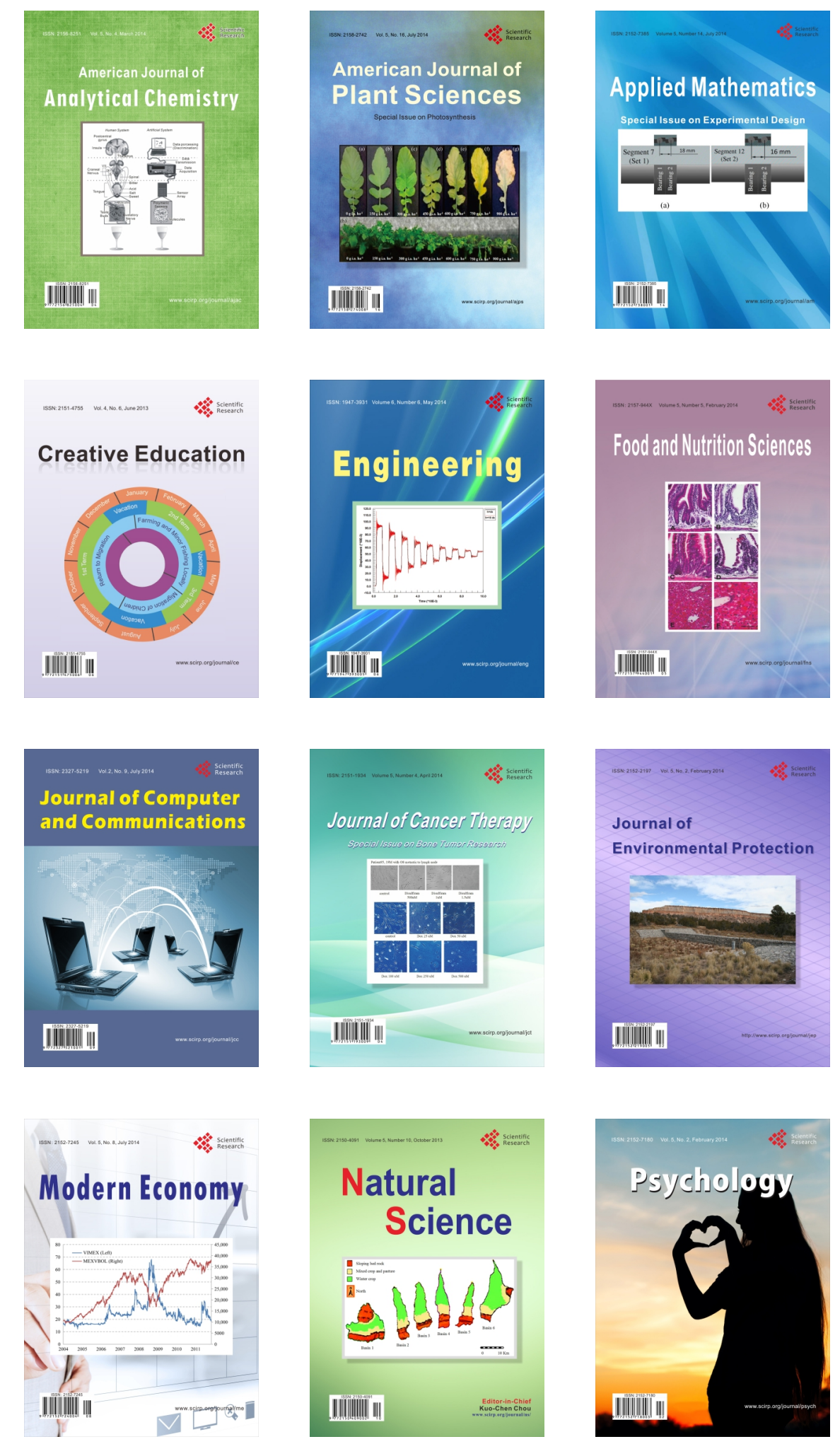